\title{
MISSÃO MARISTA NA AMAZÔNIA
}

\author{
João Gutemberg \\ Irmão Marista - Superior do Distrito Marista da Amazônia, Amazonas, AM - Brasil, e-mail: \\ gutemberg@hotmail.com
}

\begin{abstract}
A Amazônia é um dos bens mais valiosos da humanidade. Ela, com sua natureza, seu povo, sua beleza, é objeto de cuidado e carinho. Para o povo brasileiro, em geral, considerar a Amazônia significa considerar a própria vida. O cristianismo, nesse contexto, como proposta de promoção da vida, e vida em abundância, reveste-se de uma dimensão de potencialização da ética do cuidado, da preservação, da promoção da justiça, da dignidade dos povos que ali vivem, num processo de sustentabilidade responsável.

É com esse espírito de promoção e defesa da vida que o Instituto fundado por São Marcelino Champagnat se faz presente nessa terra "sagrada". Há pouco mais de quatro décadas chegaram os primeiros irmãos maristas a essa região com a finalidade de promover a educação de qualidade, somandose aos vários esforços já empreendidos por alguns setores da Igreja e do Estado. Atualmente, essa presença se faz de forma organizada e com perspectivas de consolidação cada vez mais eficaz.

Recebendo apoio institucional mais evidente, foi possível a criação do Distrito Marista da Amazônia, em julho de 2002. Este reúne as comunidades presentes nos Estados do Acre, Amazonas, Rondônia e Roraima. Há previsão de atuação também no Estado do Mato Grosso, perfazendo uma área de 3.101.405, $9 \mathrm{Km}^{2}$. De modo geral, atuam hoje no Distrito 35 Irmãos, 6 Noviços, 9 pré-noviços, formando nove comunidades religiosas, das quais a pioneira, Lábrea, foi fundada em 1967. Vários Irmãos são originários da Região. Outros são missionários que pediram transferência definitiva. Outros, ainda, são Irmãos cedidos pelas Províncias Maristas por um tempo determinado. A responsável canônica por esse Distrito é a Província Marista do Rio Grande do Sul, mas este é um espaço missionário das três Províncias Maristas do Brasil.
\end{abstract}


A missão marista na Amazônia é diversificada. A educação escolar é uma das prioridades. No entanto, os Irmãos não são proprietários das escolas. Trabalham em escolas ou universidades públicas ou conveniadas com o governo e as dioceses. Há Irmãos professores, coordenadores de ensino ou orientadores educacionais. Tem grande atuação também em diferentes tipos de pastorais: juventude, catequese, comunicação e animação vocacional. Assessoram Comunidades Eclesiais de Base e colaboram na formação e na animação da Vida Religiosa. Produzem também muitos subsídios para a educação ambiental.

A pastoral social está presente em várias comunidades que atendem crianças, adolescentes e jovens em situação de fragilidade. Algo típico da missão inculturada na Região é o atendimento a comunidades ribeirinhas e indígenas. Esse trabalho é feito por meio da Pastoral Indigenista e da Comunidade Itinerante Intercongregacional e Interinstitucional estabelecida na fronteira entre Brasil, Peru e Colômbia. Nesse processo, os Irmãos maristas atuam junto a sacerdotes, religiosos(as) e leigos(as) de diferentes organizações, de forma pobre, junto aos povos mais isolados ao longo dos rios, interior da floresta e periferia das cidades. Há o desejo da formação de uma comunidade dedicada especificamente à educação das crianças e jovens indígenas dessa Região - na língua indígena - os curumins e as cunhatãs.

Em todos os aspectos desse processo de missão, as comunidades maristas procuram ser inseridas na grande comunidade do povo. Querem ser presença significativa, com estilo de vida simples e dialogal, bem próximo ao nível da população local. Pensam numa missão mais itinerante que visa inserirse em realidades sociais necessitadas, capacitar as lideranças locais e migrar para outras fronteiras sociais mais carentes. A formação inicial acontece nas próprias comunidades apostólicas e com forte ênfase intercongregacional.

Lendo a história da presença marista nesta região, desde 1967, podemos nos alegrar pela vida gerada. $\mathrm{O}$ mundo atual requer um cuidado muito grande com o planeta, com a natureza. A Amazônia é uma riqueza para a humanidade que precisa ser preservada, defendida, valorizada. Seus povos necessitam de melhores condições de vida em harmonioso convívio com a biodiversidade que a rica natureza nos oferece. Estamos nos empenhando e gostaríamos de nos comprometer ainda mais com a educação ambiental e o desenvolvimento de uma mística ecológica que leve em conta os valores próprios dos povos da região e de todo o seu meio ambiente. 